\title{
PEMIKIRAN IBN HAZM TENTANG KEBERADAAN WALI NIKAH DALAM PERKAWINAN JANDA
}

\author{
Ahmad Fauzi \\ (Program Pascasarjana UIN Sunan Kalijaga Yogyakarta, Jln. Marsda Adi Sucipto, \\ Yogyakarta, email: vauzie_elmasy@yahoo.co.id)
}

\begin{abstract}
Abstrak
Wali nikah merupakan salah satu rukun dalam perkawinan. Begitu pentingnya keberadaan wali nikah, kajian membahas tentang keberadaan wali dalam suatu perkawinan yang dilakukan oleh janda (tsayyib), dalam perspektif Ibn $\underline{\text { Hazm. }}$ Kajian ini bersifat deskriptif analitis artinya hasil penelitian ini berusaha memberikan gambaran secara menyeluruh, mendalam tentang suatu keadaan atau gejala yang diteliti, yaitu berusaha memaparkan data secara obyektif tentang wali nikah bagi janda menurut pemikiran Ibn Hazm kemudian menganalisanya. Penelitian ini merupakan penelitian pustaka (library research) dengan menggunakan pendekatan sejarah sosial dan pendekatan ushul fiqh. Dalam menganalisis data penyusun menggunakan metode analisis isi (content analysis). Hasil penelitian menunjukkan bahwa dalam hal wali nikah Ibn Hazm sependapat dengan jumhûr ulamâ', kecuali Abû Hanîfah, yang tidak membolehkan perempuan mewalikan dirinya sendiri, tetapi harus menyerahkannya kepada walinya, yakni dari keturunan laki-laki (ashabah). Jika tidak diizinkan, maka yang menikahkan adalah sulthân. Ibn Hazm tidak membedakan antara gadis dan janda dalam hal kewajiban meminta izin wali dalam suatu pernikahan, bahwa jika ingin menikah, gadis atau janda harus dengan izin walinya.
\end{abstract}

\begin{abstract}
Bride guardian is one of pillars in the marriage. Because of its importance so this article discusses the existing of bride guardian in the marriage of a widow based on Ibn Hazm perspective. This study is analytic descriptive that means the result of this research tries to give the whole description of the condition or phenomenon researched, presenting the data objectively about the guardian bride for a widow based on Ibn Hazm perspective then analizing. It is a library
\end{abstract}


research by using social-historcal and ushîl figh approachs. In analyzing the data, the writer used content analysis method. The result of this research states that in the case of bride guardian, Ibn Hazm is in line with jumhûr ulamấ, except Abû Haniffah that do not allow the woman to be a guardian bride for herself but she has to ask her descent (ashabah) to be her guardian bride. If it is not allowed so the guardian bride is sulthân. Ibn Hazm does not differentiate between a girl and a widow in term of the obligation asking the guardian bride permission to get married.

\section{Kata-kata Kunci}

wali nikah, janda, sulthân, Ibn Hazm.

\section{Pendahuluan}

Perkawinan merupakan dasar pembentuk suatu keluarga dan institusi yang sangat penting dalam masyarakat. Eksistensi institusi ini melegalkan hubungan hukum antara laki-laki dan perempuan. Ia merupakan suatu perikatan untuk menghalalkan hubungan kelamin antara laki- laki dan perempuan dalam rangka mewujudkan kebahagiaan hidup berkeluarga yang diliputi rasa ketentraman serta kasih sayang dengan cara yang diridhai Allah swt.

Salah satu rukun pernikahan adalah wali. Menurut Abdullah Kelib, wali di dalam perkawinan adalah orang yang bertanggung jawab atas perkawinan yang dilaksanakan dibawah perwaliannya, sehingga perkawinan tidak dianggap sah apabila tidak terdapat wali yang menyerahkan mempelai perempuan kepada mempelai laki-laki. ${ }^{1}$ Berdasarkan hal tersebut, dapat disimpulkan bahwa ijab di dalam perkawinan menurut hukum Islam adalah wewenang wali sematamata. Sehingga karena peranan wali yang mempunyai arti penting akan tetap dipertahankan apabila perempuan itu tidak mempunyai wali nasab bisa digantikan kedudukannya oleh wali hakim.

Mengenai masalah perwalian, madzhab Syâfi'î, Hanbali, dan Mâliki mengatakan perlu adanya wali nikah bagi pihak perempuan, dan wali merupakan salah satu rukun yang harus ada dalam perkawinan. Tanpa adanya wali nikah maka perkawinan tidak sah. Sedangkan madzhab Hanafi mengatakan bahwa wali adalah sunnah

1 Abdullah Kelib, Hukum Islam (Semarang: PT. Tugu Muda Indonesia, 1990), hlm.11. 
hukumnya, seperti yang terdapat dalam firman Allah swt Q.S. alBaqarah (2): 234, dikatakan bahwa akad nikah yang dilakukan oleh perempuan dan segala sesuatu yang dikerjakannya tanpa menggantungkannya kepada wali atau izinnya adalah sah. Wali tidak merupakan syarat dalam perkawinan. Abû Hanîfah dan beberapa pengikutnya mengatakan bahwa ijab aqad nikah yang diucapkan oleh perempuan yang dewasa dan berakal adalah sah secara mutlak. Berdasarkan ayat tersebut Abû Hanîfah memberikan hak sepenuhnya kepada perempuan mengenai urusan dirinya dengan meniadakan campur tangan orang lain dalam hal ini adalah campur tangan seorang wali berkenaan dengan masalah perkawinan. Pertimbangan rasional logis inilah yang membuat Abû Haniffah mengatakan tidak wajibnya wali nikah bagi perempuan yang hendak menikah.2

Namun pada umumnya umat Muslim di Indonesia menganut paham madzhab Syâfi'î. Menurut madzhab Syâfi'î wali merupakan masalah penting dalam dalam pernikahan karena tidak ada nikah tanpa wali, dan wali menjadi syarat bagi sahnya suatu pernikahan. Menurut al-Syâfi'î, bagi perempuan yang hendak melangsungkan perkawinan, maka ia harus memperoleh izin dari walinya, karena seorang perempuan bila ia nikah tanpa seizin dari walinya maka tiada pernikahan baginya. ${ }^{3}$ Bila anak perempuan itu sudah bâligh, maka ia lebih berhak atas dirinya, jika bapaknya hendak menikahkan anak gadis itu, maka harus memperoleh izin darinya. ${ }^{4}$ Lebih-lebih ketika perempuan itu tsayyib (janda), maka walilah yang harus minta izin kepada tsayyib, karena tsayyib lebih berhak atas dirinya. ${ }^{5}$

Oleh karena perempuan fitrahnya adalah pemalu, maka ia harus diwakili oleh orang tuanya atau wakilnya yang bertindak sebagai wali nikahnya. Alasan lain yang menjadikan keberadaan wali menjadi sangat penting adalah dengan adanya perbedaan antara lakilaki dan perempuan. Umumnya perempuan kurang mempunyai daya tahan terhadap rasa sakit, sehingga dalam keadaan takut kadangkadang sakit yang dirasakan lebih ringan dari yang ditanggung laki-

2 Mohd. Idris Ramulyo, Hukum Perkawinan Islam (Jakarta: Bumi Aksara, 1996), hlm.218-220.

${ }^{3}$ Al-Syâfi'î, al-Umm, juz V (Bairut: Dâr al-Kutûb al-'Ilmiyah, t. th.), hlm.22.

4 Ibid., hlm.29.

5 Ibid., hlm.26. 
laki. Selain itu dalam berbagai persoalan, perempuan lebih cenderung kepada taqlîd di samping lemah dalam memahami berbagai persoalan global. Berdasarkan berbagai perbedaan tersebut dapat dikatakan bahwa perempuan cenderung takut untuk bertanggung jawab dan merasa memang perlu untuk tunduk kepada laki-laki karena pada dasarnya laki-laki merupakan panutan, pemimpin dan pelindung perempuan. Laki-laki diberi kelebihan untuk dapat menyelesaikan segala persoalan hidup jauh lebih besar dari perempuan, dan juga mempunyai wawasan, kekuatan dan keberanian.

Hal inilah yang membuat perempuan membutuhkan seorang laki-laki sebagai walinya dalam melangsungkan perkawinan yang dapat membantunya dalam menyelesaikan segala permasalahan yang mungkin timbul di kemudian hari. Perwalian di dalam istilah figh dinamakan juga wilâyah yang mempunyai makna penguasaan dan perlindungan. ${ }^{6}$

Dari berbagai macam perwalian yang ada, maka penulis akan membatasi masalah mengenai perwalian dalam pernikahan seorang janda. Karena sebagaimana tercantum dalam pasal 50 ayat (1) Undang-undang Perkawinan No. 1 Tahun 1974, yang berbunyi “ Anak yang belum mencapai umur 18 tahun atau belum pernah melangsungkan perkawinan, yang tidak berada di bawah kekuasaan orang tua, berada di bawah kekuasaan wali," dan pasal 107 ayat (1) Kompilasi Hukum Islam, yang berbunyi "perwalian hanya terhadap anak yang belum mencapai umur 21 tahun dan atau belum pernah melangsungkan perkawinan", maka suatu perkawinan yang dilakukan oleh janda tidak memerlukan seorang wali. Sedangkan adanya wali dalam suatu perkawinan termasuk dari salah satu rukun perkawinan.

Pokok permasalahan dan ruang lingkup dalam kajian ini penulis batasi pada persoalan-persoalan yang berkaitan dengan keberadaan wali dalam suatu perkawinan yang dilakukan oleh janda (tsayyib), dalam perspektif Ibn Hazm. Mengenai izin wali dalam pernikahan, Ibn Hazm mengatakan bahwa tidak sah suatu perkawinan yang dilakukan oleh seseorang, baik orang tersebut berstatus gadis atau janda tanpa izin dari walinya. Jika izin tersebut

6 Soemiyati, Hukum Perkawinan Islam dan Undang-Undang Perkawinan, Edisi Pertama (Yogyakarta: Penerbit Liberty, 1982), hlm. 41. 
tidak diperoleh, maka yang berhak menikahkan adalah sulthân. ${ }^{7}$ Menurut penulis, bahwa permasalahan ini merupakan persyaratan yang cukup mendasar untuk diterapkan pada orang yang akan melakukan perkawinan. Bagaimanakah sebenarnya metode istidlâl Ibn Hazm dalam ber-istinbâth, mengenai wali nikah

\section{Metode Kajian}

Kajian ini bersifat deskriptif analitis, artinya hasil penelitian ini berusaha memberikan gambaran secara menyeluruh, mendalam tentang suatu keadaan atau gejala yang diteliti. ${ }^{8}$ Sehingga penelitian ini diharapkan mampu memberi gambaran secara rinci, sistematis dan menyeluruh atau pengungkapan berbagai faktor yang dipandang erat hubungannya dengan gejala-gejala yang diteliti, kemudian akan dianalisis mengenai penerapan atau pelaksanaannya. Pembahasan dalam kajian ini bersifat deskriptif-analitis, artinya ia berusaha memaparkan data secara obyektif tentang wali nikah bagi janda menurut pemikiran Ibn Hazm kemudian menganalisisnya.

Untuk mendapatkan hasil yang objektif, ilmiah, dan dapat dibuktikan kebenaranya serta dapat pula dipertanggungjawabkan hasilnya, maka data dalam penelitian ini diperoleh melalui metode pengumpulan data yang dilakukan dengan menggunakan studi dokumen dengan melakukan library research (penelitian kepustakaan), yang dilakukan untuk menghimpun data, baik primer maupun sekunder yang berhubungan dengan materi penelitian.

Ada beberapa pendekatan yang digunakan dalam penelitian ini, di ataranya adalah pendekatan sejarah sosial, yakni studi tokoh dalam penelitian ini pada dasarnya mengungkapkan sejarah seseorang. Oleh karena itu, studi tokoh harus menggunakan kaidahkaidah kesejarahan yang tidak lepas dari ruang dan waktu beserta fakta-fakta sejarahnya. Oleh karena itu, produk pemikirannya itu sebenarnya bergantung pada lingkungannya itu. Melalui pendekatan ini, penelitian dilakukan dengan meneropong latar belakang

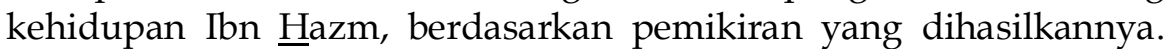
Produk pemikiran ulama, khususnya Ibn Hazm, ternyata tidak terlepas dari pengaruh kondisi sosial, politik, dan budaya serta karier

7 Ibn Hazm, al-Muhallâ, jilid IX (Damaskus: Idârah at-Tibâ'ah, 1352 H), hlm.451.

8 Soerjono Soekanto, Pengantar Penelitian Hukum (Jakarta: UI Press, 1986), hlm.10. 
intelektualnya ketika masa kehidupannya di Andalusia, yang kenyataannya saat itu didominasi oleh Madzhab Mâliki. Karena pemikiran fuqahâ itu, pada dasarnya, merupakan bagian dari suatu konteks kehidupan yang berkembang ketika pemikiran itu diformulasikan yang berhubungan dengan struktur sosial sehingga menempatkan fuqahâ dalam suatu sistem sosial sebagai sumber informasi dan tempat bertanya..$^{9}$ Kemudian selanjutnya menggunakan pendekatan ushul fiqh. Sebagaimana yang kita ketahui, bahwa hukum Islam adalah hukum yang bersumber dari al-Qur'an dan Hadits. Namun paparan rinci tentang norma-norma hukum dari kedua sumber tersebut, terutama hal-hal yang menyangkut selain ibadah belum terjangkau secara tegas, sehingga diperlukan kajian mendalam dan komprehensif guna menganalisa tujuan makna yang tersirat dari suatu nash. Untuk kajian ini, ulama melahirkan berbagai metodologi dan pendekatan kajian hukum Islam yang menjadi cabang ilmu pengetahuan tersendiri, yaitu ushul figh. ${ }^{10}$

Untuk mencapai kesimpulan yang valid, dalam menganalisis data penyusun menggunakan metode analisis isi (content analysis) ${ }^{11}$, yaitu menganalisis pemikiran hukum Ibn Hazm tentang wali nikah bagi janda, dan data-data sejarah yang berkaitan dengan hal itu. Di samping itu juga menganalisis pendapat para ulama dan sarjana lain yang berkaitan dengan permasalahan sebagai pengkayaan informasi.

\section{Ibn Hazm: Perjalanan Intelektual dan Setting Sosio-politik}

Nama lengkap Ibn Hazm adalah Ali bin Ahmad bin Sa'îd bin Hazm bin Ghalib bin Shâleh bin Khalâf bin Ma'dan bin Sufyân bin Yâzid al-Farisi. Lahir di Cordova Andalusia pada bulan Ramadhân tahun $384 \mathrm{H}$. Tumbuh sebagai orang yang terhormat dan dihormati, ayahnya Ahmad adalah seorang yang terkenal alim dan menjadi Menteri pada masa al-Manshûr Muhammad bin Abi Amir dan anaknya al-Mudaffir. Ibn Hazm pernah menjabat sebagai menteri

\footnotetext{
${ }_{9}^{9}$ Cik Hasan Bisri, Model Penelitian Figh, jilid I (Jakarta: Prenada Media, 2003), hlm.190191.

${ }^{10}$ Kamal Mukhtar, Ushul Figh (Jakarta: Jasa Usaha Mulia, 1995), hlm.1.

11 Analisis ini adalah suatu teknik penelitian untuk membuat inferensi-inferensi yang dapat ditiru (dapat dipegangi oleh peneliti-peneliti lain) dan sahih dengan memerhatikan konteksnya. Lihat Klaus Krippendroff, Analisis Isi: Pengantar Teori dan Metodologi, terj. Farid Wajidi (Jakarta: Rajawali Pers, 1991), hlm.15-20.
} 
pada masa khalifah al-Mustadhir Billâh Abd al-Rahmân bin Hisyâm pada tahun $414 \mathrm{H}$. Namun tidak lama, Abdurrahman bin Hisyâm terbunuh dan Ibn $\underline{H}$ azm dijebloskan ke dalam penjara. Pada masa Khalifah Hisyâm al-Mu'tamad Billâh bin Muhammad bin Abd alMâlik bin Abd al-Rahmân al-Nâshir, Ibn Hazm kembali diangkat menjadi Menteri, namun di tengah masa jabatannya, Ibn Hazm mengundurkan diri, dan lebih menfokuskan dirinya di dunia keilmuan. ${ }^{12}$

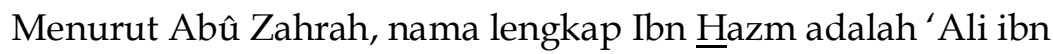
Ahmad ibn Sa'îd ibn Hazm ibn Ghâlib ibn Shâlih ibn Khalâf ibn Ma' dan ibn Sufyân ibn Yâzid. Gelar inilah yang dipakai dalam karyakaryanya, sedangkan nama populernya adalah Ibn Hazm. Ia lahir di Cordova, pada hari Rabu Subuh di akhir bulan Ramadlân tahun 384 H. bertepatan dengan tanggal 7 November 994 M13 kemudian ia meninggal dunia pada tanggal 28 Sya'bân $456 \mathrm{H}$ atau bertepatan dengan tanggal 15 Agustus $1064 \mathrm{M}$ di Manta Lisham, suatu daerah dekat Seville. ${ }^{14}$ Ia berasal dari keluarga terpandang dan berada, karena ayahnya Ahmad ibn Sa'îd tercatat sebagai Menteri (wâzir) pada masa pemerintahan al-Manshưr ibn Abû Amir dari dinasti Bani Umayyah di Spanyol. Dari segi kebangsaannya, Ibn Hazm adalah bangsa Persia. Kakeknya Yâzid adalah hamba sahaya Yâzid ibn Abû Sufyân, Gubernur di Damsyiq pada masa khalifah Umar ibn alKhaththâb. Yang pertama kali pindah ke Spanyol dari silsilah keluarga Ibn Hazm ini ialah Khalaf ibn Ma'dan pada masa 'Abd. alRahman al-Dakhil. Sebagai anak pejabat, Ibn Hazm mendapat berbagai fasilitas. Kehidupan awalnya di istana dipercayakan kepada inang pengasuh, dan dari merekalah ia memperoleh pendidikan dasar, seperti pelajaran al-Qur'an, menghafal sya'ir, belajar menulis dan keterampilan lainya. ${ }^{15}$

12 Ibn Hazm, al-Nubzâh al-Kâfiyâh fî Ahkkâm Ushâul al-Din (Beirut: Dâr al-Kutub al'Ilmiyyah, 1975), hlm.3.

13 Muhammad Abû Zahrah, Ion Hazm: Hayâtuhu, wa 'Asruhu, Arâuhu wa Fiqhuhu, (T.tp. Dâr al-Fikr al-'Arabi, 1954), hlm. 23.

14 Mahmûd 'Alî Himâyah, , Ibn Hazm: Biografi, Karya dan Kajiannya tentang Agamaagama, terj. Halid Alkaf (Jakarta: Lentera Basritama 2001), hlm. 75.

${ }_{15}$ Muhammad Abû Laylah, In Persuit of Virtue: The Moral Theology Psycology of Ibn Hazm al-Andalusi (England, London: ToHa Publisher Ltd, 1990), hlm.17. 
Meskipun secara resmi ia diasuh dan ditangani oleh inang pengasuhnya, namun ayahnya ikut memantau perkembangannya serta memperhatikan perkembangan bakatnya. Sebagaimana dituliskan oleh Amri Siregar, bahwa pada saat-saat tertentu ayahnya membawanya turut dalam acara-acara di istana raja. Di samping itu, ayahnya juga menugaskan pengawal untuk memperhatikan dan mengawasi tindak tanduk Ibn Hazm di bawah pengasuhnya para perempuan tadi. ${ }^{16}$ Dari sini dapat diketahui bahwa begitu ketat pengawasan ayahnya terhadap Ibn Hazm dalam hal akhlak dan pendidikannya.

Ketika menginjak usia remaja, kegelisahan intelektualnya terus berlanjut untuk mendalami berbagai disiplin ilmu. Hal ini tidak

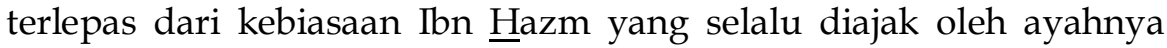
menghadiri mejelis-majelis ilmu dan budaya yang sering diadakan khalifah al-Manshûr dan dihadiri oleh para ahli sya'ir dan ilmuan. Di samping itu Ibn Hazm belajar pada seorang guru yang 'alim dan wara' yaitu Abû al-Husayn ibn 'Ali al-Farisi. ${ }^{17}$ Al-Farisi juga membawa Ibn Hazm ke majelis pengajian al-Qur'an Abû al-Qâsim Abd al-Rahmân al-Azdi (w. 410) untuk belajar bahasa arab dan hadits.

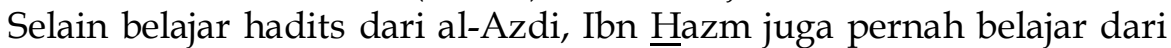
Ahmad bin Muhammad al-Jasur (w. 401). Selain, itu Ibn Hazm juga belajar menulis, diskusi, debat, sastra arab dan ilmu-ilmu syariah, nasab, pengobatan, filsafat dan lain sebagainya.

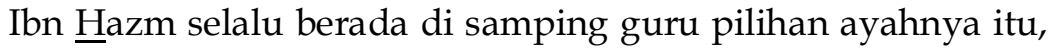
seorang guru yang melenyapkan dorongan nafsu dari murid muda usia seperti Ibn Hazm. Ketika itu, perempuan tidak berhijab di depan kaum laki-laki, menurut Ibn Hazm sudah menjadi hal biasa dalam dunia pendidikan dan pengajaran di Andalusia. Ia mulai belajar pada gurunya itu pada usia 16 tahun dan selalu menyertainya dalam rangka menghadiri halaqah-halaqah yang diselenggarakan oleh ahli tafsir, ahli hadits dan ahli bahasa Arab. Dengan kecepatan daya tangkapnya, kekuatan daya ingatnya, dan kecermatan

16Amri Siregar, Ibn Hazm Metode Zhâhirî dalam Pembentukan Sumber Hukum Islam (Yogyakarta: Belukar, 2009), hlm. 22-23.

17 Farûq 'Abd al-Mu'thî, Ibn Hazm al-Zhâhirî (Beirut: Dâr al-Kutub al-'Ilmiyyah, 1992), hlm.12. 
pemahamannya, Ibn $\underline{\text { Hazm }}$ telah menjadi pemuda yang nyaris mengungguli guru-gurunya. ${ }^{18}$

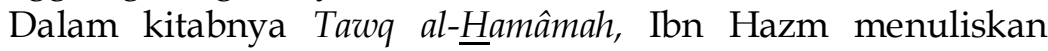
bahwa gurunya adalah Abû al-Qâsim Abd al-Rahmân ibn Abû Yâzid al-Mishri, yang mengajarkan hadis, nahwu, fiqh, lughah, retorika, dialektika dan tologi, bersama dengan Abû al-Ḧusayn ibn 'Alî al-Fâsi, di Rusafah Cordoba. Selain itu ia juga mendalami hadits dari Ahmad ibn Yasir dan Abû Bakr Muhammad ibn Ishâq al-Hamamazani. ${ }^{19}$

Kemudian Ibn Hazm belajar fiqh dari Abd Allâh ibn Dahhun, yang juga mengenalkannya dengan kitab al-Muwaththa' karya monumental Mâlik bin Anas. Di samping itu, ia juga belajar filsafat, adab, hadis, rijal hadits dari Abû Abd Allâh Muhammad ibn alal-Majidi. Kemudian ia belajar sejarah dari al-Faradi, belajar filologi dari ibn Abd al-Wârid dan belajar filsafat, logika dan ilmu alam dari ibn al-Qaththâni (w. 420/1029).20

Adapun guru Ibn Hazm yang sangat memengaruhi kerangka berfikirnya adalah Abû al-Khiyât Mas'ûd ibn Sulayman ibn Muflid (W. 426/1034). Dialah yang kemudian mengajarkan tentang pemikiran madzhab Zhâhiri, dan membentuk pola pemikirannya, yang akhirnya menjadi ahli hukum yang idependen dan menolak mengikatkan diri pada suatu madzhab tertentu. Sejak awal, Ibn Hazm memang telah menununjukkan hasrat yang besar terhadap dunia ilmu pengetahuan. Di samping mendapatkan ilmu dari para gurugurunya, ia juga rajin belajar sendiri, menghadiri berbagai diskusi dan sanggup berargumentasi ketika menghadapi berbagai permasalahan yang aktual yang diperdebatkan dengannya. ${ }^{21}$ Saat Ibn Hazm berusia lima belas tahun terjadi fenomena yang tragis dalam perjalanan sejarah Islam di Andalusia, kekuasan kaum Amiriyah memasuki ambang kehancuran, yang menjadi tanda penghapusan kekhalifahan di Andalusia. Peristiwa itu terjadi pada tahun 422 H/1021 dan peritiwa itu merupakan titik awal runtuhnya kejayaan Islam di semenanjung Iberia. Kondisi politik yang tidak menentu ini

18Abd al-Rahmân al-Syarqawi, A'immah al-Figh al-Tis'âh, terj. al-Hamid Husayni, (Bandung: Pustaka Hidayah, 2000), hlm. 580.

${ }^{19}$ Abû Zahrah, Ibn Hazm: Hayâtuhu, hlm. 35.

20 Abu Laylah, "An Introduction to the Life and Work of Ibn Hazm", The Islamic Quarterly, volume XXIX, no. 2 (1985), hlm. 82-83.

${ }^{21}$ Ibid. 
menyebabkan keluarga Ibn $\underline{\text { Hazm }}$ berpindah-pindah, dari satu tempat ke tempat lain, yaitu berpindah dari tempat kediamannya di Madinah, bagian timur Codova, berpindah kebagian Barat, yaitu Balad Mugirah, pada tahun $339 \mathrm{H}$. peristiwa itu terjadi, setelah Muhammad Ibn Hisyâm al-Mahdi yang baru menjabat selama tiga hari sebagai khalîfah, yaitu bulan Jumadil Akhir 339/Februari 1009, dan dengan adanya peristiwa itu Ibn Hazm akhirnya berpindah mengikuti jejak ayahnya. 22

Merasa kehilangan perlindungan sebab ditinggal mati oleh ayahnya, Ibn Hazm akhirnya pindah ke Armeria pada tahun 404 H/1014 M dalam usia 20 tahun. Di tempat yang baru ini Ibn Hazm merasa lebih nyaman, dan ia melanjutkan pengambaraan intelektualnya dengan belajar bahasa Arab, nahwu dan hadits kepada gurunya Abû al-Qâsim Abd al-Rahnân ibn Yâzid al-Azdi.

Ibn Hazm mulai belajar tentang hukum Islam secara khusus pada usia 26 tahun dari seorang guru yang bernama Abd Allâh ibn Yahyâ ibn Ahmad ibn Dahun, yang merupakan mufti Cordoba, dari situlah ia belajar al-Muwaththâ' karya Mâlik. Dengan sendirinya, Ibn Hazm mendapat ilmu fiqh yang bersumber dari Madzhab Mâliki. Hal ini mengingat bahwa madzhab yang dominan di Andalusia saat itu adalah madzhab Mâliki bahkan menjadi madzhab resmi negara.

Setelah mempelajari fiqh madzhab Mâliki, Ibn Hazm mendalami fiqh madzhab Syâfi'î, sebuah madzhab yang kurang begitu populer di Andalusia. Dari buku-buku sejarah tercatat bahwa

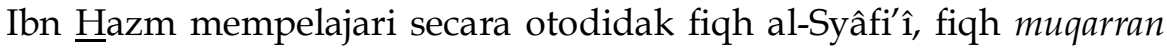
(fikih Perbandingan), tafsir dan hadis dari kitab-kitab karya ulamaulama yang amat tinggi nilainya seperti kitab tafsir karya Baqi' ibn Makhlad dan kitab Ahkâm al-Qur'ân karya Ibn Umayyah al-Hijâzi, ulama bermadzhab Syâfi'î, serta kitab tafsir karya seorang pembela madzhab Zhâhiri, Abû al-Hakam Mundzir ibn Sa'îd.

Dengan bekal ilmu yang luas yang didapat dari guru-gurunya dan kitab-kitab yang dibacanya, serta karunia intlektualitas yang amat tinggi ditambah kondisinya yang selalu berpindah-pindah yang dimanfaatkannya untuk mengembara mencari ilmu, Ibn Hazm banyak melakukan diskusi dan perdebatan dengan ulama-ulama

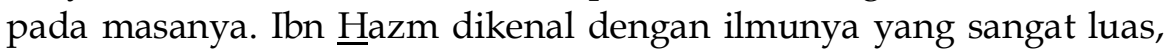

22 Abû Zahrah, Ibn Hazm: Hayâtuhu, hlm. 42. Lihat juga Siregar, Ibn Hazm, hlm. 24. 
sehingga ia tidak hanya dikenal sebagai muhaddits dan fâqih, namun ia juga adalah seorang yang ahli diberbagai bidang seperti ushul fiqh, sastra arab, sejarah, mantiq, filsafat, ilmu kalam, dan ilmu

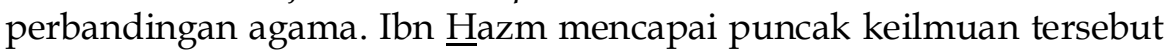
di atas, karena beberapa hal23, yaitu: (1) Keadaan pribadi dan kekuatan jiwa yang dilimpahkan Allah kepadanya; (2) guru-guru yang mengarahkan; (3) usaha pekerjaan yang menyebabkan seorang dapat menghadapi ilmu dengan sempurna; dan (4) keadaan lingkungan.

Pada Mulanya, Ibn Hazm belajar fikih madzhab Mâliki sebagai madzhab yang banyak dianut masyarakat Andalusia kala itu. Dia belajar kitab karangan Mâlik yang terkenal yaitu al-Muwaththa' kepada Ahmad bin Duhun (mufti Cordova), sehingga benar-benar menguasai fikih Mâlik. Di samping belajar fikih madzhab Mâlikî, dipelajari juga kitab Syâfi'î yang mengkritik Mâlik dalam masalah ushûl dan furu' yaitu ikhtilâf al-Mâlik. Dari pengalaman inilah dia berpindah dari madzhab Mâlikî ke madzhab Syâfi'î. Pemahamannya terhadap madzhab Syâfi'î membuat dia kagum terhadap prinsipprinsip yang dipegang oleh al-Syâfi'î sehingga menjadikannya orang yang fanatik berpegang teguh pada madzhab tersebut. Ibn Hazm kembali tidak puas, akhirnya Ibn Hazm berpindah madzhab dan lebih condong kepada madzhab Zhâhirîyyah dengan Imâmnya Dawûd bin Alî bin Khalâf al-Asbuhâni $(202-270 \text { H. })^{24}$

Kepindahan Ibn Hazm ke madzhab Zhâhirî didukung oleh kondisi yang ada pada abad III H. Banyak ulama Cordova yang belajar ke Timur seperti Baghdad yang menjadi pusat dinasti Abbasiyah. Di antara ulama Cordova yang belajar ke Baghdad adalah Baqqu bin Mukhâlid, Abû Abd Allâh bin Wahbah Bazbazi dan Qâsim bin Asbagh bin Muhammad bin Yûsuf. Mereka tertarik kepada madzhab Zhâhirî setelah tidak puas dengan madzhab yang mereka

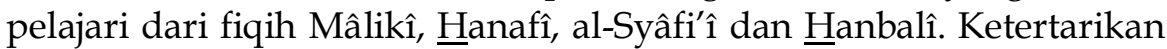
mereka adalah karena madzhab Zhâhirî hanya terikat kepada alQur'an dan al-Sunnah. Di tangan merekalah madzhab Zhâhirî berkembang di Andalusia. Hal lain yang mendorong Ibn Hazm

${ }^{23}$ Hasbi as-Siddieqy, Pokok-Pokok Pegangan Imam Madzhab (Semarang: Pustaka Rizki Putra, 1997), hlm. 554.

${ }^{24}$ Ibn ㅂazm, al-Ushûl wa al-Furu' (Kairo: Dâr al-Nahdah al-'Ilmiyyah, 1978), hlm. 5. 
adalah kondisi Andalusia kala itu yang mencapai puncak keilmuan. Pada saat itu lahir ulama-ulama terkenal yang luas ilmunya dalam segala disiplin ilmu, seperti Ibn Abd Barr.

Dalam kapasitasnya sebagai Gubernur Madinah dan sekaligus sebagai ulama hadits, dia pernah diminta oleh Khalîfah Umar ibn abd al-Azîz untuk menuliskan hadits-hadits Nabi SAW yang ada pada 'Umrah binti Abd al-Rahmân (W. 98 H) serta al-Qâsim ibn Muhammad (W.107 H) dan Ibn Hazm lantas menuliskannya 'Umrah adalah paman dari Ibn Hazm sendiri, pernah tinggal bersama 'Aisyah dan dia adalah yang paling terpecaya dari kalangan tâbi' în dalam hal hadits 'Aisyah. ${ }^{25}$

Di samping ilmu-ilmu keislaman Andalusia terkenal dengan ilmu-ilmu filsafat yang melahirkan filosof-filosof Muslim seperti Ibn Rusyd dan Ibn Bajah, kondisi tersebut didukung juga oleh penguasa waktu itu yaitu Abd al-Rahmân al-Nâshr yang berkuasa selama lima puluh tahun. Dia mendatangkan ulama-ulama Timur, membangun perpustakaan, dan mendatangkan kitab-kitab yang berkembang di Timur pada waktu itu. Pada mulanya, Ibn Hazm terjun di dunia politik, namun perjalanan politik yang dilaluinya tidak sesuai dengan ide-ide yang diharapkannya. Politik cenderung berorientasi kepada kekuasaan dan nafsu, sedangkan Ibn Hazm adalah seorang ilmuan yang ikhlas dan jujur sehingga Ibn Hazm keluar dari dunia politik dan menekuni bidang ilmiyah membaca mengajar dan menulis. Ibn Hazm selalu mengembangkan pendapatnya di mana saja dia berada, seperti ketika dia berada di Valensia, Cordova, dan lain-lain. Namun setelah penguasa Valensia, Ahmad bin Rasyîd, meninggal dunia,

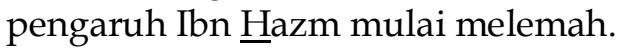

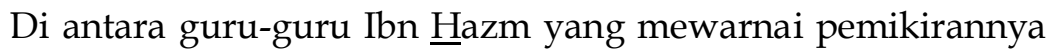

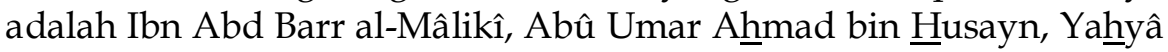
bin Mas'ûd, Abû al-Khiyâr Mas'ûd bin Sulaymân al-Zhâhirî, Yûnus bin Abd Allâh al-Qâdli, Muhammad bin Sa'îd bin Sa'i, Abd Allâh bin al-Râbi' al-Tamîmi, Abd Allâh bin Yûsuf bin Nâmi. Ibn Hazm juga mempunyai beberapa murid setia yang menyebarkan pendapatpendapatnya, ${ }^{26}$ di antara mereka adalah, Abû Abd Allâh al-Humaydi,

${ }^{25}$ Nawir Yuslem, Ulumul Hadits (Jakarta: PT Mutiara Sumber Widya, 2001), hlm. 468. ${ }^{26}$ Muhammad Abû Zahrah, Târîkh al-Madzâhib al-Islâmiyyah (kairo: Mathba'ah alMadani, t.th.), hlm. 434. 
Surayh bin Muhammad bin Surayh al-Muqbirî, Abû Râfi', Abû Usamah Ya'qûb, Abû Sulaymân al-Mus'ib, Abû Muhammad bin alMaqribi.

Kondisi politik Andalusia pada masa kecil Ibn Hazm berada dalam keadaan aman dan tenteram di bawah kekuasaan dan kepemimpinan Abû 'Amir Muhammad ibn Abû 'Amir (al-Manshûr) dan anaknya Abd al-Mâlik. Namun ketika Ibn 'Amir wafat dan anaknya juga wafat pada tahun $339 \mathrm{H}$, berakhirlah kekuasaan dinasti al-'Amiriyyah (yang masih satu garis keturunan dengan Mu'âwiyah) sekaligus menjadi awal mula munculnya kekacauan dan pemberontakan. ${ }^{27}$

Masyarakat Andalusia terdiri dari berbagai unsur dan masingmasing memiliki ciri dan aliran tertentu. Di Andalusia terdapat orang Arab yang murni kearabannya yang memengaruhi peradaban Andalusia. Terdapat pula bangsa Barbar yang bertabiat kasar, di samping penduduk asli yang sudah beragama Islam. Penduduk asli Spanyol dikenal dengan sebutan bangsa 'ajam terklasifikasi menjadi beberapa golongan, pertama Musalamat, yaitu penduduk asli Spanyol yang telah memeluk Islam, kedua, Muwalladin, yaitu yang merupakan keturunan Musalamat yang lahir dari perkawinan campuran dengan imigran Arab, ketiga, Musta'ribat, yaitu penduduk asli Spanyol yang masih tetap beragama Kristen tetapi telah berasimilasi dengan suku Arab, mereka berbudaya dan berbahasa Arab. ${ }^{28}$

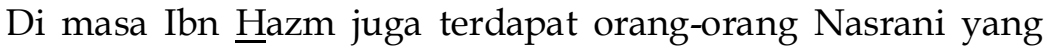
berbaur dengan orang-orang Islam. Dalam masyarakat yang majemuk terjadi akulturasi budaya dan dengan perantara pergaulan itu ditransfer kebudayaan-kebudayaan ke Barat. Perhubunganperhubungan yang erat antara golongan Islam dan Nasrani menimbulkan hubungan dan perdebatan-perdebatan agama. Bahasa Arablah yang menyatukan penduduk Andalusia dan mengumpulkan mereka dalam satu kebudayaan, bahasa Arablah yang menjadi wadah pikiran-pikiran dan hasil-hasil karya yang tumbuh pada waktu itu. ${ }^{29}$

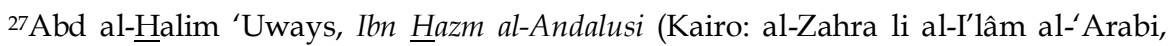
1988), hlm. 20.

28 Al-Thahir Makkî, Dirâsat 'an Ibn ㅂazm (T.tp.: Maktabah Wabiyyah, 1397 H), hlm. 13-21.

${ }^{29}$ As-Shiddieqy, Pokok-Pokok Pegangan, hlm. 562. 
Andalusia dikuasai oleh umat Muslim pada zaman khalifah al-Wâlid ibn Abd al-Mâlik (705-715 M), yaitu seorang khalifah dari Bani Umayyah yang berpusat di Damaskus. Sebelum memasuki Andalusia umat Muslim telah menguasai terlebih dahulu wilayah Afrika Utara, dan Hasan Nu'man al-Gasani bertindak sebagai gubernurnya di bawah khalifah al-Mâlik (685-705 M). Ketika khalifah al-Wâlid berkuasa, gubernur Afrika digantikan oleh Mûsâ ibn Nusair, dan memperluas wilayahnya sampai Aljazair dan Maroko. Wilayahwilayah ini pada awalnya dikuasai oleh kerajaan Romawi, yaitu kerajaan Gothik. ${ }^{30}$ Jauh sebelum 'Abd al-Rahmân ibn Mu'âwiyyah yang terkenal dengan gelar al-Dakhil datang ke Andalusia pada tahun $755 \mathrm{M}$ setelah dinasti Umayyah dikalahkan Bani Abbas, negeri tersebut sesunguhnya telah menjadi daerah Islam. Bahkan sejarah mencatat hampir 20 orang gubernur telah memerintah di sana selama Dinasti Umayyah yang berpusat di Syiria (Damsiq) berkusa. Ekspansi ke wilayah ini terjadi di zaman kakek 'Abd al-Rahmân yaitu Khalifah al-Wâlid ibn 'Abd al-Mâlik (w. 703 M), khalifah keenam dari empat belas khalifah dinasti Umayyah, melalui kebijakan gubernurnya di Afrika Utara, Mûsâ ibn Nusair. Oleh karena itu, mengikuti keterangan-keterangan yang diberikan oleh ahli sejarah, kedatangan 'Abd al-Rahmân ibn Mu'âwiyyah ke Andalusia laksana menyiram bibit tanaman sehingga tumbuh subur dan kuat. Maksudnya, ia datang untuk memimpin kembali wilayah moyangnya, yang dahulu menjadi satu propinsi dengan daulah Umayyah. Lalu ia pun menjadi gubernurnya di wilayah tersebut yang secara nominal tunduk kepada kekhalifahan Bani 'Abbas yang berpusat di Baghdad. ${ }^{31}$

Hal ini menunjukkan bahwa meskipun secara nominal ia masih menundukkan diri kepada Khalifah di Baghdad, namun ia masih merasa bahwa dialah yang lebih berhak diangkat menjadi gubernur di sana. Status sebagai propinsi dari khalifah Bani 'Abbas ini mereka pandang cukup memadai, walaupun sesunggunya ada keinginan untuk melepaskan diri sama sekali.

30 Badri Yatim, Sejarah Peradaban Islam, cet VII (Jakarta: Raja Grafindo Persada 1998), hlm. 87-88.

31 Cerita lolosnya Abd al-Rahmân al-Dakhil ini sangat banyak ditulis oleh para sejarawan. Lihat misalnya dalam Phillip K. Hitti, The Arabs a Short History (London \& New York: Macmillan, t. th.), hlm.159. 
Status ini tetap bertahan hingga masa Abd al-Rahmân yang bergelar al-Nâshr yang merupakan gubernur kedelapan dari turunan Bani Umayah di Spanyol. Namun kemudian status keamiran tersebut ditinggalkan, dan ia memproklamasikan dirinya sebagai khalifah yang berarti pula secara politik lepas dari kekuasaan Bani Abbas yang berpusat di Baghdad. Peristiwa politik ini terjadi pada Bulan Ramadhan tahun $316 \mathrm{H}$. bersamaan dengan bulan Januari tahun 929 M. namun meskipun terdapat perubahan status, dari segi administrasi pemerintaan Abd al-Rahmân III secara umum tidaklah mengalami banyak perubahan. Yang menjadi penting bagi adanya perubahan ini adalah dari sudut pandang syari'ah (hukum Islam). Seorang khalifah menurut hukum Islam, di samping memiliki kekuasaan duniawi (temporal), ia juga memiliki kekuasaan diniyyah (keagamaan) yang mengharuskan umat tunduk dan patuh kepadanya. Tidak demikian halnya bagi penguasa setingkat amir. ${ }^{32} \mathrm{Di}$ samping itu tentunya secara psikologis dan kepuasan batin bagi keturunan Bani Umayyah dengan berdirinya kembali kekhalifahan Bani Umayyah yang telah lenyap selama 150 tahun lebih.

Sesudah masa keemasan ini, Spanyol pun sebagai halnya belahan lain dunia Islam, memasuki masa disintegrasi. Sebab setelah wafatnya al-Hakam, ia digantikan oleh anaknya Hisyam al-Muayyad, yang diketika itu baru berusia 10 tahun. ${ }^{33}$ Mudah dibayangkan situasi macam apa yang bakal terjadi dari pengangkatan sebagai khalifah tersebut. Dikarenakan usianya yang masih muda, banyak orangorang disekelilingnya mempunyai kepentingan, salah satunya adalah Abû Amir. Oleh karena itu untuk melaksanakan tugas-tugas kenegaraannya diangkatlah al-Manshur ibn Abû 'Amir, yang sesunggunya tidak mempunyai hubungan darah dengan Bani Umayyah. Dalam melaksanakan tugas-tugas kekhalifahan ini, alManshûr yang memang bukan berasal dari unsur Arab itu menyusun pembantu-pembantu (menteri) yang juga bukan berasal dari unsur Arab. Dari jajaran menteri itu tersebutlah nama Ahmad ibn Sa'îd, ayah dari Ibn $\underline{\text { Hazm. }}{ }^{34}$ Dalam sejarah pemerintahan Islam di Spanyol

${ }^{32}$ Al-Abbadi, al-Mujmâl fî Târikh al-Andalus (T.tp.: Dâr al-Qalam, t. th.), hlm. 120.

${ }^{33}$ Himâyah, Ion Hazm wa Minhâjuh, hlm. 26.

${ }^{34}$ Abû Zahrah, Ibn Hazm; Hayâtuhu, hlm. 41. 
ini kedudukan al-Manshur sebagai pelaksana tugas-tugas khalifah tersebut dikenal sebagai lembaga al- $\underline{H} \hat{a} j i b .35$

Abû Amir termasuk orang yang piawai dalam berpolitik, sehingga dengan kepiawaiannya itu dan didorong oleh ambisiusnya, menjadikan khalifah muda dibuat seakan seperti boneka. Bahkan pada tahun $981 \mathrm{M}$, dia justru memindahkan admisnistrasi dari istana khalifah di Cordoba dan Madinat al-Zahrah ke istana baru yang dibuatnya sendiri al-Madinah al-Zahra. Pada tahun yang sama, 981 M. Ibn Amir terlibat petempuran yang dibantu oleh tentara Barbar dan tentara bayaran Kristen melawan Jenderal Ghâlib (mertuanya), yang dibantu pangeran Kristen dari Utara, dan berakhir dengan kemenangan di pihak Abû Amir. Setelah kembali ke Cordoba di menobatkan dirinya begelar al-Manshûr Billâh. ${ }^{36}$

Setelah al-Manshûr meninggal dunia pada tahun 392 H/1002 M digatikan oleh anaknya Abd al-Mâlik al-Muzaffar. Dia berhasil mempetahankan stabilitas politik selama enam bulan. ${ }^{37}$ Namun setelah memakai gelar al-Muzaffar pada tahun 1007, justru ia meninggal dunia dengan misterius. Dia telah membuktikan sebagai seorang administrator yang tangguh dan jenderal kelas satu, seperti ayahnya.38 Setelah al-Muzaffar, kepemimpinan digantikan oleh saudaranya, Abd al-Rahmân al-Manshûr yang terkenal dengan julukan Syanjul. Ia terkenal berperangai jelek terhadap penduduk Andalusia karena karakteristik ayahnya (al-Manshûr) dan saudaranya (al-Muzaffar) tidak ia warisi. ${ }^{39}$ Ketika terjadi pertempuran dengan pemberontak, Muhammad ibn Hisyam al-Mahdi (399-400 H/1009$1010 \mathrm{M})$ yang didukung oleh tentara Barbar mampu mengalahkan Abd al-Rahmân dan menggantikan posisinya sebagai khalifah.40

Dengan berpindahnya kekuasaan khalifah ke tangan al-Mahdi inilah Dawlah 'Amiryyah berakhir dan kekuasaan pun kembali dipegang oleh Bani Umayyah. Akan tetapi sisa masa pemerintahan

35 Montgomery Watt, A History of Islamic Spain (Eidenbergh: The University Press, 1977), hlm. 81-82.

36 Abû Zahrah, Ibn Hazm; Hayâtuhu, hlm. 81.

37 K. Ali, Sejarah Islam dari Awal hingga Runtuhnya Dinasti Umayyah (Tarikh praModern), terj. Ghufron A. Mas'Udi (Jakarta: Raja Grafindo Persada, 1996), hlm. 312.

38 Watt, A History, hlm. 84.

${ }^{39}$ Himâyah, Ibn Hazm, hlm. 27.

${ }^{40}$ Ali, Sejarah Islam, hlm. 312. 
Bani Umayyah ini hanya ditandai oleh perebutan kekuasaan dan pergolakan-pergolakan yang berkepanjangan. Pada masa inilah Ibn Hazm hidup, bahkan sebagimana ayahnya, ia pun sempat menceburkan diri ke dalam bidang politik. Meskipun ia bukan keturunan Arab, akan tetapi di bidang politik ia mendukung Bani Umayyah. ${ }^{11}$ Bahkan ia sempat diangkat menjadi menteri tiga kali oleh Khalifah Bani Umayyah, yaitu oleh Muhammad ibn 'Abd al-Mâlik yang bergelar al-Murtadlâ tahun 1016 M, lalu oleh Abd al-Rahmân ibn Hisyâm al-Mustadzir tahun 1023 M., dan yang terakhir oleh Hisyâm ibn Muhammad al-Mu'tad tahun 1029-1031 M. Ia merupakan khalifah terakhir Bani Umayyah di Spanyol. Sejak itu, tidak ada lagi khalifah di Spanyol dan mulailah timbul kerajaan-kerajaan kecil (almulûk al-tawâa if). Ibn Hazm masih sempat menyaksikan pergolakan politik di bumi Spanyol selama sisa hidupnya.

Sejauh itu, penting dicatat bahwa pada masa-masa yang penuh pergolakan tersebut, kerajaan-kerajaan Kristen yang ada di sebelah utara Spanyol serta wilayah-wilayah lainnya sedikit demi sedikit membangun kekuatan dan melakukan konsolidasi serta mengadakan hubungan dan kotak satu sama lain. Bahkan ada juga di antaranya yang menjalin kerjasama dengan kerajaan-kerajaan Islam yang sudah terpecah kepada kerajaan-kerajaan kecil. Dalam kerjasama itu termasuk bantuan mempertahankan kerajaan-kerajaan Islam tersebut dari ancaman musuh. ${ }^{22}$ Dengan demikian kerajaankerajaan Kristen itu mulai memperoleh peranan dalam percaturan politik di Spanyol. Kekuatan inilah yang kelak, meskipun masih dalam rentang waktu yang panjang sebagai terbukti kemudian, yang di komandani oleh Raja Ferdinand dan Ratu Isabela menjadi cikal bakal kekuatan Kristen yang berhasil menghalau umat Muslim dari bumi Spanyol.

Secara singkat dikemukakan bahwa pada tahun 1609 M., melalui perintah pengusiran yang ditandatangani oleh Raja Philip III boleh dikatakan tidak ada lagi orang Islam di sana. Mereka telah pindah ke kota-kota di pantai Utara Afrika. Keadaan demikian terjadi, karena kekuatan-kekuatan Kristen yang bangkit ini tidak ingin melihat orang Islam lagi di Spanyol. Mereka mengultimatum

41 Siregar, Ibn Hazm, hlm. 46.

42 Ibid., hlm. 47. 
penduduk yang beragama Islam dengan dua alternatif, yaitu masuk Kristen atau keluar dari Spanyol.43

Meskipun hapusnya Islam di Spanyol masih lama setelah Ibn Hazm, namun baginya peristiwa-peristiwa perebutan kekuasaan yang disaksikannya, membuat ia meninggalkan lapangan politik, ia pun memusatkan perhatiannya ke dunia ilmiah. Dalam bukunya alTalkhis li Wujûh al-Talkhis yang dikutip oleh Amri Siregar, Ibn Hazm mengecam keras raja-raja kecil yang menguasai Spanyol di ujung masa kejayaan Islam di sana, yang karena ambisinya mereka rela meminta bantuan kepada raja-raja Krsiten di sekitarnya. Ia juga mengecam para ulama yang mendukung pemerintahan raja-raja tersebut. Ternyata kecaman-kecamannya itu membawa akibat timbulnya kemarahan-kemarahan para penguasa dan ulama-ulama kepadanya, sehingga Ibn Hazm dianggap sebagai oposisi terhadap kekuasaan efektif, yang lebih tragis dari keadaan ini ialah

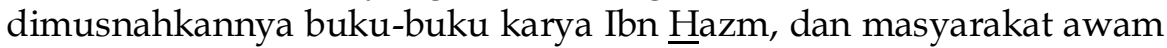
pun didoktrinasi untuk tidak berinteraksi dengannya. ${ }^{4}$

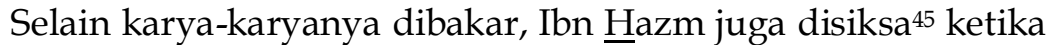
ia melawat ke Seville, saat penguasanya adalah al-Mu'tadid ibn 'Abbâd (439-464 H). Kehidupan yang awalnya saling menghargai dan toleransi antara berbagai kelompok masyarakat, yang menjadi modal utama kemajuan peradaban, justru semakin memudar yang salah satu penyebabnya adalah hilangnya kewibawaan penguasa di mata masyarakat. Hal tersebut memaksa Ibn Hazm kembali mudik ke kampung halamannya dan memusatkan perhatiannya penuh pada bidang keilmuan. Menurut Hasbi as-Siddieqy, motif penguasa membakar buku-buku Ibn Hazm di antaranya adalah: (1) Kebencian Ulama Mâlikîyah yang menguasai masyarakat kepada Ibn Hazm; (2) kekhawatiran penguasa kepada usaha Ibn Hazm mengembalikan kekuasaan kepada bani Umayyah, dan keberaniannya mengkritik pemerintah. 46

43 Al-Abbâdî, al-Mujmâl fi Târikh, hlm. 100.

${ }^{44}$ Siregar, Ibn Hazm, hlm. 48.

45 Abû Zahrah, Ibn Hazm, hlm. 44. Menurut Abû Zahrah, motif pembakaran karyakarya Ibn Hazm selain karena kritikannya terhadap penguasa, adalah karena provokator para ulama kepada penguasa karena pendapat-pendapat Ibn $\underline{H}$ azm yang bertolak belakang dengan ulama Madzhab Mâlikî sebagai madzhab resmi Negara.

${ }^{46}$ Ash-Shiddieqy, Pokok-Pokok Pegangan, hlm. 594. 
Masa Ibn $\underline{\text { Hazm }}$ boleh dikatakan masa Andalusia mencapai puncak ilmu. Semangat keilmuan yang marak di belahan Timur dunia Islam mendapat sambutan yang baik di wilayah Barat, khalifah-khalifah Bani Umayyah di Spanyol ini sekurang-kurangnya hingga masa al- Hakam ibn Abd al-Rahmân II adalah tokoh-tokoh pecinta Ilmu pengetahuan. Dari segi poitik pun pada abad ke $4 \mathrm{M}$. sampai paro abad kelima Hijriyyah adalah masa-masa stabil dan kondusif bagi pengembangan segala bidang kehidupan termasuk bidang ilmu pengetahuan. Bahkan pada masa kepemimpinan khalifah al-Hakam II, kehidupan umat Muslim Andalusia dapat menyaingi kejayaan peradaban pada masa Bani Abbasiyyah di Baghdad. ${ }^{47}$

Sarana-sarana penunjang berupa bangunan-bangunan sekolah pun banyak didirikan. Universitas Cordova yang semula bangunannya disatukan dengan masjid, diperluas dan dilengkapi prasarananya. Di Universitas ini terdapat mahasiswa-mahasiswa Islam dan Kristen dari beberapa daerah, seperti Afrika, Asia, Eropa dan Spanyol sendiri.48 Pada masa ini, Universitas Cordova yang dibangun al-Hakam II sudah dilengkapi fasilitas perpustakaan dengan koleksi bukunya mencapai 400.000 buah buku. ${ }^{49}$ Perpustakaan yang dibangun ini menjadi pusat penelitian ilmu pengetahuan. Bahkan Ibn Hazm pun melakukan studi diperpustakaan ini. Dengan fasilitas perpustakaan yang megah, Andalusia betul-betul sebagai pusat kajian ilmu pengetahuan yang mampu menciptakan masyarakat yang berilmu. ${ }^{50}$

Kurang lebih sekitar tahun 183-286 H./800-900 M. Andalusia pernah mencapai perkembangan hukum yang sangat pesat. Pada masa ini madzhab hukum yang mengalami perkembangan diantaranya adalah Hanafî, Syâfi'î, Mâlikî, Hanbali dan Zhâhirî. ${ }^{51}$ Selain hukum, juga berkembang kajian dalam bidang hadits, bahasa, sastra, sejarah dan lain-lain. Hal ini terlihat dari pengembaraan ilmiah Ibn Hazm, terlihat bahwa banyak guru Ibn Hazm dalam bidang ini,

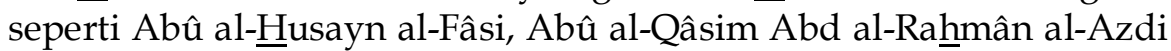

47 Yatim, Sejarah Peradaban Islam, hlm. 97.

${ }^{48}$ Hitti, History, hlm.169.

${ }^{49}$ Ali, Sejarah, hlm. 31.

${ }^{50}$ Abû Zahrah, Ibn Hazm, hlm. 207.

51 Watt, A History, hlm. 62-63. 
(w 410 H), Abd Allâh ibn Yahyâ ibn Ahmad ibn Dahun (w. 403 H), seorang mufti Cordoba. ${ }^{52}$ Di samping itu, terdapat ulama Abû alKhiyâr Mas'ûd ibn Sulaymân ibn Muflit, yang merupakan salah satu guru Ibn Hazm, dan telah memberikan kesan yang mendalam dalam melakukan studi dan pemikiran. ${ }^{33}$

Dalam bidang prosa dan bahasa juga pesat, tercatat tokoh dalam bidang ini ada Ibn Sidâ' (396-457 H./1006-1066M). Ia merupakan seorang Lexicographer, dengan karyanya berupa kamus bahasa Arab yang termasyur di Barat dan Timur. Abû Bakr al-Turfusî, yang juga dikenal dengan Ibn Abî Randaqa, ia adalah seorang sastrawan dengan karya monumentalnya Sirâj al-Mulûk. Yûsuf ibn alSyaykh dari Malaga, yang terkenal dengan penulis alphabetical dan seorang penulis tentang fenomena alam. ${ }^{54}$

Ibn Hazm sebagaimana dilihat dari riwayat hidupnya tumbuh dalam keluarga yang cinta akan ilmu pengetahuan atau minimal pada masa itu sudah menjadi simbol status bagi orang-orang berada apabila di rumahnya terdapat koleksi buku-buku. Oleh sebab itu, Abû Zahrah berkesimpulan bahwa tidak ada alasan untuk tidak mengakui keutamaan Ibn Hazm dibidang ilmu pengetahuan. Sebab dengan mengambil acuan kepada Abû Hanîfah sewaktu ditanya orang tentang bagaimana caranya memperoleh ilmu pengetahuan, ia menjawab, "saya hidup di perut besarnya ilmu, saya lama bergaul dengan alim ulama". Hal serupa ini telah ditemukan pada Ibn Hazm yang berasal dari Cordoba ini, ia pun hidup di perut besar ilmu dan sejak dini telah bergaul dengan ulama. 55

Namun demikian, dari ilmu yang diperoleh dan bacaan serta pengalaman hidup, terbentuklah kepribadian akalnya yang mengagumkan sehingga membuat dirinya tercatat dalam sejarah. Ia telah mampu membuat aliran fiqh tersendiri yang berbeda dengan ulama sezamannya yang berbeda dengan ulama-ulama lain. Walaupun Ibn Hazm merupakan pengikut madzhab Zhâhirî namun bukanlah peniru dari Abû Dawûd. Tetapi manhaj-nyalah yang mampu mengungkapkan hukum dari al-Qur'an dan Sunnah tanpa

52 Abû Zahrah, Ibn Hazm, hlm. 215.

53 Ibid.

54 Watt, A History, hlm. 112.

55 Abû Zahrah, Ibn Hazm, hlm. 104. 


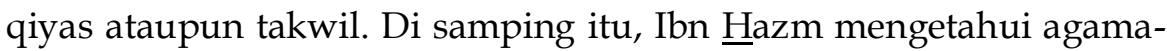
agama dan madzhab-madzhab di luar Islam, mengetahui firqah yang tumbuh dalam masyarakat Islam. Dan semua ulama mengakui hal ini. Oleh karena itu, Ibn Hazm merupakan ulama yang paling banyak karyanya dalam hukum Islam. ${ }^{56}$

Di antara keistimewaan Ibn $\underline{H} a z m$ adalah karyanya yang banyak dan memengaruhi pemikiran manusia. Banyak pencari ilmu yang belajar dari karya-karya Ibn Hazm. ${ }^{57}$ Beragam kesusahan dan kesengsaraan yang dialami oleh Ibn Hazm telah mendorongnya untuk melahirkan karya yang bermanfaat.

Apabila Abû Fadl meriwayatkan bahwa karya-karya ayahnya (Ibn Hazm) dalam beragam disiplin ilmu yang pembahsannya mencapai 8000 lembar. Sejarah telah mencatat beberapa kitab yang kembali dan yang hilang karena adanya pergolakan dan hujatan baik dari lawan-lawannya maupun mereka yang bersimpati, yang berusaha mendukung penguasa Sevilla untuk menyobek-nyobek dan membakar karya-karyanya. Dalam peristiwa ini, Ibn Hayyan berkomentar, "karya-karya Ibn $\underline{H}$ azm begitu banyak, bagaikan onta yang penuh muatan. Belum terhitung pada kolong lemarinya yang bertingkat yang tidak disukai para ahli hukum dan ulama, sehingga sebagiannya dibakar di Sevilla dan disobek secara terang-terangan. Sikap mereka yang demikian justru membuat Ibn $\underline{H}$ azm terus menerus memperbanyak karyanya." Di antara karya-karyanya adalah:

1. Al-Ihkâm fî Ushûl al-Ahkkâm (Penguatan Dasar-dasar Hukum)

Terhadap kitab ini, Ibn Hazm berkomentar, "kebenaran tidak akan bertentangan, dalil kebenaran (burhan) tidak akan dirusak oleh dalil lainnya, dan saya telah menceritakan hal ini dalam al-I $\underline{h} k \hat{a} m$ fi Ushêl al-Ahkâm yang tidak perlu saya mengulanginya." Kitab ini telah diterbitkan oleh Syaykh Ahmad Syakir pada $1345 \mathrm{H}$ melalui penerbit "al-Sa'adah" sebanyak 8 juz, lalu diterbitkan lagi oleh alImâm yang berkedudukan di Mesir sebanyak dua jilid, masingmasing terdiri dari 4 juz, di bawah bimbingan Dr. Zakariya Ali Yusuf.

56 Ibid, hlm. 553.

57 Lihat bukunya Himâyah, Ibn Hazm: Biografi, hlm. 82-104. Baik yang terlacak maupun yang tidak terlacak. 
1. Idzâr Tabdil al-Yahûd wa al-Nashârâ li al-Tawrâh wa al-Injîl wa Bayân Tanaqudl Mâ bi Aydihim mimmâ lâ Yahtamil al-Ta'wîl (Membuktikan Perubahan yang Dilakukan Umat Yahudi dan Kristen atas Taurat dan Injil serta Pertentangan di Antara Mereka yang Tidak Memungkinkan Takwil). Al-Zhahabi dalam Tadzkirah al-Huffâzh mengatakan bahwa karya ini juga terdapat dalam al-Fishâl dari halaman 116 ((juz I) sampai halaman 74 (juz II).

2. Al-Ushîl wa al-Furû' (Pokok-pokok Agama dan Cabangnya). Kitab ini merupakan manuskrip yang ditemukan di Lembaga Manuskrip Arab pada Katalog Tauhid nomor 133 yang memuat risalah-risalah Ibn Hazm. Karya ini berjumlah 90 halaman yang pada masingmasing halaman terdiri dari 23 baris. Sebagian tulisannya jelas dan sebagian yang lain susah dibaca. Kitab ini diterbitkan oleh Maktabah al-Nahdlah al-'Arabiyyah. Kitab ini adalah ringkasan kitab al-Fishâl.

3. Asmấ al-Shahabah wa al-Ruwah (Nama Para Sahabat dan Perawi)

Di dalamnya disebut nama-nama sahabat yang menerima hadits dari Nabi, orang-orang setelahnya dan setelahnya lagi, yaitu beribu-ribu pengikut yang meriwayatkan hadits. Demikian seterusnya sampai kemudian kepada masing-masing personal yang meriwayatkan terakhir. Karya ini terdapat dalam Jawâmi' alSirah halaman 275-315.

4. Asmấ al-Khulafấ' al-Mahdiyyîn wa al-A'immah Umarâ' al-Mu'mîn (Nama Para Khalifah dan Pemimpin Umat Mukmin).

5. Ashâb al-Fatayâ min al-Shahâbah wa min Ba'dihim 'alâ Maratibihim fí Katsrah al-Fatayâ (Para Sahabat Muda dan Sesudahnya Menurut Tingkatan Jumlah Terbanyak). Di dalam karya ini Ibn Hazm menceritakan para sahabat muda Nabi menurut jumlah terbanyak, yaitu dimulai dari mereka yang tinggal di Makkah, Madinah, Basrah, Syam, Mesir, dan di kota-kota lain.

6. Al-I'râb 'an al-Hairah wa al-Iltibas al-Waqi'în fî̀ Mazhâhib Ahl Ra'y wa al-Qiyâs (Kebingungan dan Keraguan Para Ahli Ra'yi dan Qiyas). Juz I dari kitab ini terdapat dalam perpustakaan milik seorang alim bernama Syaykh Muhammad Thahir bin 'Asyur yang terletak di pangkalan laut $16 \overline{\mathrm{km}}$ dari kota Tunisia. Sedangkan juz II ditemukan di perpustakaan Tustarbaiti di Dublin, ibu kota Irlandia. 
Ahmad Fauzi

7. Ibthâl al-Qiyâs wa al-Ra'y wa al-Istihsân wa Taqlîd wa Ta'lîl (Membatalkan Qiyas, Ra'yi, Istihsan, Taqlid dan Ta'lil). Karya ini tersimpan di perpustakaan Gutah.

8. Al-Taqrîb Lihad al-Manthîq wa al-Madkhâl Ilayh bi al-Fadz wa al'Amiyyah wa al-Amtsilah al-Fiqhiyyah (Definisi dan Pendekatan Mantiq melalui Lafadz-lafadz Umum dan Contoh-contoh Fiqhiyyah). Karya ini diterbitkan oleh Maktabah al Hayah, Beirut dan di-tahqîq oleh Dr. Ihsan Abbas dengan berpegang pada satu naskah yang ada di perpustakaan al Ahmadiyah Universitas alZaytunah, Tunisia.

9. Al-Tawqif 'alâ Syâri' al-Najâh Bikhtisar al-Târiq (Bersikap pada Dzat Pemberi Keselamatan). Diterbitkan dan dicetak oleh Dr. Ihsan Abbas dan ada dalam kitab Majmû'ah Rasâ'il Ibn $\underline{\text { Hazm. }}$.

Tidak dapat diragukan lagi bahwa Ibn Hazm adalah seorang pakar dibidangnya. Hal tersebut dapat kita lihat dari komentar beberapa tokoh, seperti Abû Hâmid al-Ghazâli yang berkata, "Saya melihat buku-buku karangan Ibn Hazm, semuanya menunjukkan kecerdasannya dan kekuatan hafalannya". Al-Hâfidz Abû Abd Allâh Muhammad bin Futuh al-Humaydi berkata, "saya tidak pernah melihat sosok seperti ibn Hazm yang memiliki kecerdasan, kekuatan hafalan, kemuliaan, dan keteguhan menjalankan agama". Izz al-Dîn bin Abd alSalam berkata, "saya tidak pernah melihat dalam buku-buku keislaman yang sebanding dengan al-Muhallâ karangan Ibn $\underline{H} a z m$ ". Menurut Muhammad Abû Zahrah,58 Ibn Hazm mempunyai talenta yang membentuknya menjadi ulama besar, ditambah kemampuan hafalannya yang sangat luar biasa. Di samping hafal hadis-hadis Nabi, Ibn Hazm juga hafal di luar kepala fatwa-fatwa para sahabat dan tabi'in.

Ibn Hazm bukan hanya sekedar menghafal apa yang dia pelajari tapi dia juga mempunyai katajaman analisis, sehingga dalam

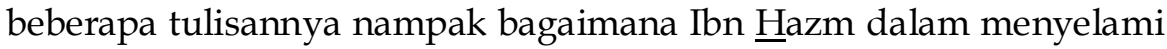
masalah yang dibahasnya hingga ke dasar, sebagaimana dalam kitab al-Milâl wa al-Nihâl dan kitab Thûq al-Hamâmah yang membahas manusia dari sisi kejiwaan. Di samping kemampuan yang tinggi, Ibn Hazm juga terkenal dengan sifat ikhlasnya, keikhlasan, dan tidak

58 Muhammad Abû Zahrah, Târîkh al-Madzâhib al-Islâmiyyah (Kairo: Mathba'ah alMadani, t.th.), hlm.396. 
adanya tendensi apa-apa menjadikan Ibn Hazm sebagai sosok ulamâ' yang berani, tegas dan lugas. Menyuarakan apa yang diangapnya sebagai kebenaran, dengan ucapan dan tulisan, tanpa memikirkan apakah hal tersebut menguntungkan dirinya atau bahkan merugikan. Keberanian tersebut dapat dilihat dengan jelas dalam buku-bukunya.

Dengan karya-karya yang sedemikian banyaknya, nama Ibn Hazm menjadi masyhur, banyak orang yang datang untuk belajar kepadanya, sekalipun banyak ulamâ' yang merasa tidak senang kepadanya. Karya-karyanya itu merupakan kontribusi berharga bagi khazanah pemikiran Islam, disamping juga memberi pengaruh sangat besar bagi penyebaran ide serta paham-paham pemikirannya di dunia Islam pada masa-masa sesudahnya.

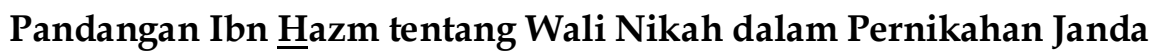

Dalam pandangan madzhab Syâfi'î, Mâlikî, dan Hanbali, wali merupakan syarat sah dalam pernikahan, 59 sehingga dianggap tidak sah apabila pernikahan tidak memakai wali.60 Sedangkan Abû Hanîfah mengatakan bahwa perempuan yang telah bâligh dan berakal sehat boleh memilih sendiri suaminya dan boleh pula melakukan akad nikah sendiri, baik dia perawan maupun janda. Tidak seorang pun yang mempunyai wewenang atas dirinya atau menentang pilihannya, dengan syarat, orang yang dipilihnya itu se-kufǘ (sepadan) dengannya dan mahar-nya tidak kurang dari mahar mitsil. Tetapi bila dia memilih seorang laki-laki yang tidak se-kufü' dengannya, maka walinya boleh menentangnya, dan meminta kepada

\footnotetext{
${ }^{59} \mathrm{Hal}$ ini didasarkan pada surat al-Baqarah (2): 221, “Dan janganlah kamu nikahkan perempuan-perempuan mukminat dengan laki-laki musyrik sebelum mereka beriman". Ayat ini ditujukan kepada wali nikah. Demikian pula dalam surat al-Baqarah (2): 232, "Janganlah kamu menghalang-halangi mereka (para isteri) untuk menikah kembali dengan bekas suami mereka jika mereka saling meridoi dengan cara yang ma'ruf". Ma'qil bin Yasar menceritakan bahwa ayat ini turun berkenaan dengan dirinya. Katanya, "saya menikahkan salah seorang saudara perempuanku dengan seorang laki-laki, tetapi kemudian diceraikannya. Ketika iddahnya habis, ia datang lagi meminangnya." Maka saya jawab, "dulu kamu saya jodohkan, saya nikahkan dan saya muliakan, tetapi kemudian kamu ceraikan. Dan kini kamu datang untuk meminangnya lagi. Demi Allah kamu tidak dapat kembali lagi kepadanya untuk selama-lamanya". Lelaki ini orangnya biasa saja, tetapi bekas istrinya itu ingin kembali kepadanya. Dalam hadits Abû Mûsâ, sesungguhnya Rasulullah telah bersabda, "tidak sah nikah tanpa wali".

${ }^{60}$ Wahbah al-Zuhaylî, al-figh al-Islâmi wa Adillatuhû, juz VII (Berut: Dâr al-Fikr, 1985), hlm. 192.
} 
qâdhî untuk membatalkan akad nikahnya bila mahar mitsil tersebut tidak dipenuhi oleh suaminya. ${ }^{61}$

Terkait dengan perwalian dalam pernikahan, pada dasarnya Ibn Hazm sependapat dengan jumhûr ulama', kecuali Abû Hanîfah, yang tidak membolehkan perempuan mewalikan dirinya sendiri, tetapi harus menyerahkannya kepada walinya, yakni dari keturunan laki-laki (ashabah), jika tidak diizinkan maka yang menikahkan adalah sulthân. 62

Namun kemudian, Ibn Hazm tidak membedakan antara gadis dan janda dalam hal kewajiban meminta izin wali dalam suatu pernikahan, bahwa jika ingin menikah, gadis atau janda harus dengan izin walinya. Secara tegas, ia menyatakan:

$$
\begin{aligned}
& \text { لايحل للمرأة نكاح ثيبا كانت أوبكرا الا باذن وليها الأب أو الإخوة أو الجحد أو الأعمام او بنى الاعمام }
\end{aligned}
$$

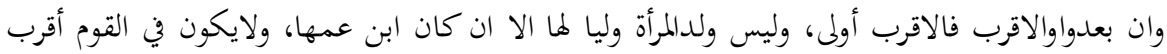

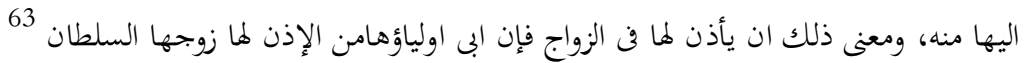

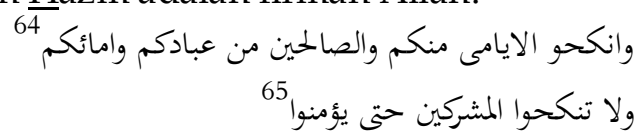

${ }^{61}$ Muhammad Jawad Mughniyah, Fiqih Lima Madzhab, terj. Masykur A. B., Afif Muhammad, dan Idrus al-Kaf (Jakarta: PT. Lentera Basritama, 2000), hlm. 345.

62 Ibn Hazm, al-Muhallâ, juz IX (Mesir: Idârah at-Thibâ'ah, 1352 H), hlm. 469.

63 Ibid, hlm. 451.

64 Al-Qur`an,. al-Nûr (32).

65 Al-Qur`an, al-Baqarah (221). 
Menurut Ibn Hazm ayat tersebut di atas ditujukan kepada para wali, bukan kepada para perempuan.

$$
\text { لإن اشتحح المرأة بغير وليها فان نكحت فنكاحها باطل ثلاث مرات فإن أصابها فلها مهرها بما أصاب منها }
$$

Diceritakan dari Thâriq ibn Wahab ibn Jurayj dari Sulaymân dari 'Aisyah r.a. Rasulullah bersabda: "Jangan engkau nikahkan seorang perempuan itu tanpa walinya, dan apabila tetap menikah maka nikahnya menjadi batal. Kata batal, beliau mengulanginya sebanyak tiga kali, dan apabila sudah terlanjur maka wajib membayar maharnya. Dan apabila ada perselisihan maka sulthân menjadi wali bagi perempuan yang tidak ada walinya tersebut." 66

Maka, tidak seorang pun dari gadis atau janda yang dapat menikah, kecuali dengan izin wali. Sebab telah ada nash yang menjadi bayân atas kewajiban menikah dengan izin wali. Kata apa pun yang menjadi bayân nash atas suatu hukum, itulah yang dikehendaki Syâri' atas ketetapan-ketetapan-Nya.

Di samping ketentuan di atas, Ibn Hazm juga mendasarkan pada beberapa Hadits dan Atsar Sahabat. Ada pun di antara Hadits yang dijadikan dasar, yaitu:

$$
\begin{aligned}
& \text { لاتنكح المرأة بغير وليها فان نكحت فنكاحها باطل ثلاث مرات فإن أصاما فلها مهرها بما أصاب منها }
\end{aligned}
$$

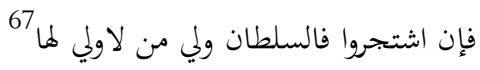

$$
\begin{aligned}
& \text { لانكاح إلا بولي } 68 \\
& \text { لا تنكح المرأة الا بإذن وليها اوذوى الرأي من اهلها او السلطان. عن عمر بن دينار عن عبد الرحمن ان } \\
& \text { عمر بن الخطاب رد نكاح امرأة نكحت بغير إذن وليها }
\end{aligned}
$$

66 Ibn Hazm, Al-Muhallâ, juz IX (Mesir: Idârah at-Thibâ'ah, 1352 H), hlm. 451.

${ }^{67}$ Hadis riwayat 'Aisyah dengan jalur Ibn Wahhab dari Ibn Jurayj dari Sulaymân Ibn Mûsâ dari Ibn Syihab dari Urwah Ibn al-Zubayr. Ibid, jilid IX, hlm. 451.

68 Hadis riwayat Ahmad Ibn Muhammad al-Talnaki dari Ibn Mufajjar dari Muhammad Ibn Ayyûb al-Smut al-Raqqi dari Ahmad Ibn Amr Ibn Abd al-Khâliq alBazzar dari Abû Kâmil dari Basyar Ibn Manshûr dari Sufyân al-Sawri dari Ishââ alSabil dari Bardah Ibn Abî Mûsâ al-Asy'ârî dari ayahnya. Ibid, IX, hlm. 452.

${ }^{69} \mathrm{Ibn}$ Hazm, al-Muhallâ, juz IX, hlm. 454. 
Umar bin Khaththâb berkata, tidak boleh menikahkan seorang perempuan kecuali dengan izin walinya atau seseorang yang pintar dari keluarganya atau sulthan. Dari Umar bin Dinâr, bahwasanya Umar ibn Khaththâb pernah mengulangi nikahnya seorang perempuan yang menikah tanpa izin walinya. Dari Abû Hurayrah, bahwasanya tidak boleh seorang perempuan yang melakukan akad nikah tanpa adanya wali dan tidak diperbolehkan seorang perempuan menikahkan dirinya sendiri. Ibn Abbâs berkata seorang pelacur itu adalah mereka menikahkan dirinya sendiri tanpa adanya wali.

Abû Tsûr berkata, tidak diperbolehkan seorang perempuan menikahkan dirinya sendiri dan menikahkan orang lain. Sedangkan Abû Sulaymân berkata, "ada pun seorang gadis tidak boleh menikah tanpa adanya izin walinya, sedangkan bagi janda boleh menyerahkan urusannya kepada siapa saja yang dia inginkan dan tiada bagi walinya untuk menentang hal itu".

Abû Hanifah berkata bahwa boleh bagi perempuan menikahkan dirinya sendiri tanpa adanya izin walinya dengan syarat harus menikah dengan yang se-kufü'. Apabila tidak se-kufû', maka walinya boleh memisahkan antara keduanya. Lain halnya dengan Abû Yûsuf, beliau berkata bahwa tidak ada nikah kecuali dengan izin walinya. ${ }^{70}$

Terkait dengan penolakannya terhadap qiyâs, dalam hal ini Ibn Hazm juga menolak qiyas yang dilakukan oleh Abû Hanîfah dan Zufar, bahwa 'illah kebolehan perempuan menikahkan dirinya sendiri adalah kekufuan, sehingga jika perempuan menikahkan dengan lakilaki yang tidak se-kufü', maka ayah dapat membatalkan pernikahan tersebut dan berhak pula tidak setuju atas mahar mitsil anak perempuannya. ${ }^{71}$ Juga pendapat al-Awzâ'i yang menambahkan bahwa wali tidak dapat mencegah pernikahan anak perempuannya jika menikah dengan laki-laki yang se-kufû̀ dan keduanya telah melakukan hubungan suami istri. Dasarnya adalah Hadits:

$$
\text { السلطان ولي من لاولي لها27 - الت }
$$

70 Ibid, jilid IX, hlm. 455.

${ }^{71} \mathrm{Ibn}$ Hazm, al-Muhallâ, jilid IX, hlm. 455-456.

72 Ibid. 
Sulthân (penguasa) menjadi wali bagi siapa saja yang tidak mempunyai wali.

Ibn Hazm juga menyanggah pendapat yang membolehkan perempuan menyerahkan perwalian nikahnya kepada orang (Muslim) yang dikendakinya disebabkan adanya percekcokan antara wali dan anaknya.73 karena menurutnya, setiap perempuan itu melekat pada keturunan laki-laki (ashabah) bukan atas perempuan lain, sehingga sangatlah mustahil tidak ada satu pun wali yang tidak dapat menikahkan. Jika pun terjadi percekcokan, keluarga yang tidak mungkin didamaikan sehingga tidak ada wali yang mau menikahkan, maka diserahkan kepada sulthân. ${ }^{74}$ Ibn Hazm berkata, bahwa sabda Rasulullah yang berbunyi: " إيا امرأة نكحت بغير إذن وليها فنكاحها باطل "berlaku bagi setiap perempuan yang akan menikah, baik perempuan itu berstatus janda maupun masih perawan. ${ }^{75}$

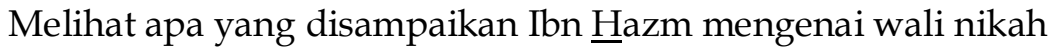
bagi janda di atas nampak corak Zhâhirî dalam pengambilan dalil. Hal ini memang cukup beralasan mengingat sikap Zhâhirîyah yang diambil oleh Ibn Hazm ini lebih merupakan metode kritik yang diterapkan pada sumber atau landasan hukum dari pada sebuah zahirisme dalam arti literalis. Kecenderungan Ibn Hazm terhadap corak pemikiran Zhâhirîyah ini merupakan model kerangka berfikirnya tentang penjelasan maksud syara' yang terdapat dalam alQur'an dan Sunnah. Penjelasan maksud Syâri' yang terdapat dalam nash sudah sedemikian jelas, sehingga dapat dipahami sesuai dengan maksud aslinya, sebagaimana yang ia katakan :

$$
\text { قول الله تعالى يجب حمله على ظا هره مالم ميمنع من حمله على ظاهره نص اخر } 76
$$

Menurutnya, bahwa firman Allah harus dipahami sesuai dengan makna zhahiriyahnya selama tidak terhalang oleh nash yang lain. Makna zhâhirîyah nash menurutya merupakan lafazh yang terdapat dalam al-Qur' an dan Sunnah yang digunakan untuk mencari

73 Abû Tsûr yang mengatakan bahwa perempuan dapat menyerahkan perwalian nikahnya kepada tiap orang (Muslim) yang dikehendaki disebabkan adanya percekcokan antara wali dan anaknya. Ibid.

${ }^{74} \mathrm{Ibn}$ Hazm, al-Muhallâ, juz IX, hlm. 455-456.

75 Ibid, hlm. 457.

${ }^{76} \mathrm{Ibn}$ Hazm, al-Fishâl fî al-Milâl wa al-Ahwâ' wa an-Nihâl, jilid II (ttp: Dâr al-Fikr, 1317), hlm. 122. 
hukum segala sesuatu yang memerlukan penyelesaian. ${ }^{77}$ Dengan pemahaman ini, dapat dikatakan bahwa yang disebut nash sebagaimana penjelasan dia di atas adalah zhahir itu sendiri, atau lebih tepatnya pemahaman zhâhirîyah terhadap nash, baik al-Qur'an maupun Sunnah.

Pengertian tersebut dapat dipahami bahwa corak pemikiran Ibn Hazm yang bersifat zhâhirîyah merupakan pemahaman yang diambil secara lahiriyah terhadap sumber hukum, baik berupa alQur'an ataupun Sunnah. Sejak awal sudah ditegaskan bahwa kecenderungan pemikirannya yang sejalan dengan madzhab Zhâhirî bukan berarti taqlîd terhadap madzhab ini, tetapi dia konsisten terhadap sikapnya yang terkait dengan al-Qur'an dan Sunnah.

Menurut Ibn Hazm, konsekuensi pemahaman literalis terhadap nash, adalah tidak boleh ditakwilkan atau dialihkan maknanya dari makna hakiki kapada makna majâzi (kiasan), kecuali pengalihan ini didasarkan atas petunjuk al-Qur'an, Sunnah, ijmâ' atau sesuai dengan makna yang ditangkap oleh indera dan pengalihan makna itu harus tercakup pengertian lafazh secara kebahasaan. Menurutnya, makna yang dipahami semacam ini mengandung pengertian lahiriyah dan bukan termasuk takwil. ${ }^{78}$

Berdasarkan pemahaman ini, Ibn Hazm menyebutkan analisis tentang makna yang terdapat dalam al-Qur'an dan Sunnah yang mengandung perintah dan larangan. Nash yang mengandung perintah menunjukkan kewajiban menjalankan perbuatan dan menuntut kesegeraan. Sebaliknya, yang mengandung larangan menunjukan kewajiban untuk meninggalkannya dengan kesegeraan. ${ }^{79}$

Ibn Hazm mengatakan, sebagian besar kelompok Zhâhirî memahami setiap ungkapan yang berisi perintah untuk melaksanakan kewajiban atau larangan untuk mengerjakannya, yang terdapat dalam al-Qur'an dan Sunnah. Di samping itu, Ibn Hazm menyebutkan bahwa lafazh yang bersifat umum dan khusus, harus dipahami berdasarkan lahiriahnya. Hal ini mengandung maksud

77 Ibn Hazm, al-Ihkâm fì Ushûl al-A $\underline{h} k \hat{a} m$, jilid II (Beirut: Dâr al-Kutûb al-`Ilmiyyah, 1985), hlm. 42.

78 Ibid, jilid III, hlm. 313.

79 Ibid. 
bahwa keumuman dapat dipahami oleh akal pikiran tanpa melalui penalaran, karena sesuai dengan tuntutan makna dan cakupan bahasanya. Secara jelas dia mendefinisikan, bahwa yang disebut dengan lafazh umum adalah mengartikan lafazh dengan satuansatuannya yang dikehendaki menurut bahasa. Sedangkan lafazh khusus adalah mengartikan lafazh dengan sebagian makna atau satuan yang tercakup dalam lafazh menurut bahasa dan mengesampingkan yang lain. .0

Menurut Ibn Hazm, sebagaimana dikutip oleh Abû Zahrah, bahwa lafazh umum dan khusus itu terbagi menjadi tiga; pertama, lafazh khusus yang mengandung maksud khusus. Dengan pengertian ini lafazh sudah menunjukkan maknanya secara khusus. Kedua, lafazh umum yang mengandung maksud umum, maksudnya, lafazh ini harus diartikan sesuai dengan maknanya yang dikehendaki menurut bahasanya. Ketiga, lafazh umum yang bermakna khusus, ${ }^{81}$ dengan berdasarkan makna kebahasaan tersebut dapat dipahami bahwa dalam memahami nash, baik al-Qur'an maupun Sunnah Ibn Hazm lebih mengedepankan makna literalisnya.

Ide dan paham pemikiran Ibn Hazm tampaknya berpengaruh besar di dunia Muslim pada masa-masa sesudahnya. Menurut Abû Zahrah, ada tiga faktor yang menyebabkan pemikiran-pemikiran Ibn Hazm mempunyai pengaruh yang cukup berarti di dunia Muslim..$^{82}$

Pertama, karya-karyanya yang sangat banyak meliputi berbagai bidang ilmu, terutama kitab-kitab fiqh dan ushul fiqh yang merupakan kitab-kitab kodifikasi madzhab al-Zhâhirî. Kedua, usaha keras Ibn Hazm dengan mengajak orang-orang mengikuti madzhabnya walaupun banyak ulama yang dengki kepadanya, kedengkian mereka justru menaikkan popularitas Ibn Hazm. Ketiga, adalah banyaknya pemuda yang menjadi muridnya, yang dengan semangat penuh keikhlasan mengoleksi kitab-kitabnya dan menyebarkan dan menyebarkan paham-pahamnya.

Ibn Taymiyah bahkan pernah membaca dan mengkritik kitabkitab karya Ibn Hazm, sehingga bahasa dan ungkapan yang

80 Ibid., jilid I, hlm. 43.

81 Ibid, jilid III, hlm. 338-389 dan Abû Zahrah, Ibn Hazm, hlm. 372-373.

82 Abû Zahrah, Târikh al-Mazâhib, hlm. 399. 
dipakainya dalam kitab-kitabnya hampir serupa dengan gaya bahasa

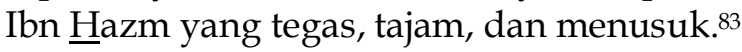

Semangat ijtihâd dan kembali kepada al-Qur'an dan al-Sunnah seperti diserukan Ibn Hazm akhirnya kembali bangkit dengan munculnya ulama-ulama yang mendukung seruannya seperti Ibn Taymiyah (661-728 H), mujtahid abad kedelapan Hijriyah dan Muhammad ibn Abd Allâh al-Syawkâni (1173-1250 H), mujtahid abad kedua belas Hijriyah. Metode ijtihâd Ibn Hazm terdapat dalam kitabnya al-Ihkâm fî̀ Ushûl al-Ahkkâm. Menurutnya, ijtihâd merupakan persoalan penting yang wajib diketahui maknanya oleh semua umat Muslim. ${ }^{84}$ Ijtihâd adalah memanfaatkan kemampuan untuk mencari hukum dari sesuatu yang terjadi di mana didapati hukumnya itu tidak ada perselisihan di antara para ahli ilmu tentang kebenaran agamanya. 85

Di isi lain, dari segi ketersediaan aturan hukum, Ibn Hazm termasuk orang yang memandang bahwa ajaran Islam ini telah lengkap dan sempurna dan tidak ada satu masalah pun yang luput dari cakupannya. Paradigma serupa ini dirujuknya kepada ayat-ayat al-Qur'an, di antaranya:

$$
\begin{aligned}
& \text { اليوم اكملت لكم دينكم واتممت عليكم نعمتي ورضيت لكم الاسلام دينا } 86 \\
& \text { ما فرطنا في الكتاب من شيء ثم الى ربهم يحشرون } 87 \\
& \text { ونزلنا عليك الكتاب تبيانا لكل شيء في فئ } 88
\end{aligned}
$$

Berdasarkan ayat-ayat tersebut, Ibn Hazm dan Ahl al-Zhâhir sampai kepada kesimpulan bahwa seluruh masalah yang terjadi di alam ini telah tersedia ketentuan hukumnya di dalam nash. ${ }^{89} \mathrm{Nash}$ yang telah sempurna ini, difahami apa adanya sesuai dengan bahasa atau tekstualnya. Menurut Ibn Hazm, konsekwensi pemahaman literalis terhadap nash, adalah tidak boleh ditakwilkan atau dialihkan maknanya dari makna hakiki kepada makna majâzi, kecuali pengalihan ini berdasarkan atas petunjuk al-Qur'an, Sunnah dan

${ }^{83}$ Muhammad Abû Zahrah, Ibn Taymiyah (Beirut: Dâr al-Fikr al-Arabiy, t.th.), hlm. 32.

84 Ibn Hazm, al-Ihkâm, jilid VIII, hlm. 133.

85 Ibid.

86 Al-Qur`an, al-Mâidah (3).

${ }^{87}$ Al-Qur’an, al-An'âm (38).

88 Al-Qur`an, al-Nahl (89).

$89 \mathrm{Ibn}$ Hazm, al-Nabjhât, hlm. 16-17. 
Ijmâ', atau sesuai dengan makna yang ditangkap oleh indera dan pengalihan makna itu harus tercakup pengertian lafazh secara kebahasaan. Menurutnya, makna yang difahami semacam ini mengandung pengertian lahiriyah dan bukan termasuk takwil. ${ }^{90}$

\section{Penutup}

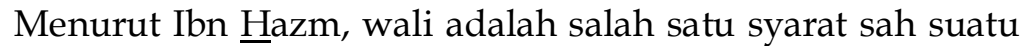
perkawinan, karena walilah yang menjadikan akad nikah itu menjadi sah. Bahwasanya, perempuan kalau menikah wajib minta izin kepada walinya, baik itu janda maupun perawan. Apabila mereka (para wali) tidak bisa, maka sulthân dapat bertindak sebagai wali. Perkawinan bila tanpa izin dari orang tua/walinya, maka nikahnya batal. Pemikiran Ibn Hazm mengenai izin wali dalam pernikahan janda, tidak berbeda dengan mayoritas ulama termasuk al-Syâfi'î. Dalam hal ini menurut al-Syâfi'î, nikah tidak sah tanpa adanya wali, dan perempuan yang hendak melangsungkan perkawinan, ia harus mendapat izin walinya, karena tanpa izin tersebut perkawinan yang dilangsungkan adalah batal, baik perempuan tersebut berstatus gadis maupun janda. Pemikiran Ibn Hazm tentang izin wali dalam pernikahan janda (tsayyib) masih relevan dengan zaman sekarang ini dan bisa diterapkan, karena tidak bertentangan dengan al-Qur'an dan Hadits.

\section{Daftar Pustaka:}

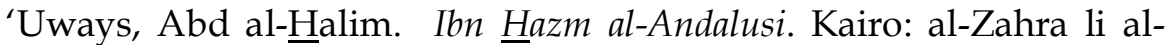
I'lâm al-'Arabi, 1988.

Abbadi, Al-. al-Mujmâl fî Târikh al-Andalus. T.tp.: Dâr al-Qalam, t. th.

Abû Laylah, Muhammad. In Persuit of Virtue: The Moral Theology Psycology of Ibn Hazm al-Andalusi. England, London: ToHa Publisher Ltd, 1990.

Abû Zahrah, Muhammad. Ibn Hazm: Hayâtuhu, wa 'Asruhu, Arâuhu wa Fiqhuhu,. T.tp. Dâr al-Fikr al-'Arabi, 1954.

Abû Zahrah, Muhammad. Ibn Taymiyah. Beirut: Dâr al-Fikr al-Arabiy, t.th.

Abû Zahrah, Muhammad. Târîkh al-Madzâhib al-Islâmiyyah. kairo: Mathba'ah al-Madani, t.th.

${ }^{90} \mathrm{Ibn}$ Hazm, al-Ihkâm, Jilid I, hlm. 42. 
Ali, K. Sejarah Islam dari Awal hingga Runtuhnya Dinasti Umayyah. Tarikh pra-Modern), terj. Ghufron A. Mas'Udi. Jakarta: Raja Grafindo Persada, 1996.

Al-Syâfi'î. al-Umm, juz V. Bairut: Dâr al-Kutûb al-'Ilmiyah, t. th.

Al-Syâthibî. al-Muwâfaqât fî Ushûl al-Syarî'ah, jilid I. Mesir: AlRahmâniyyah, t.th.

Ash-Siddieqy, Hasbi. Pokok-Pokok Pegangan Imam Madzhab. Semarang: Pustaka Rizki Putra, 1997.

Bisri, Cik Hasan. Model Penelitian Figh, jilid I. Jakarta: Prenada Media, 2003.

Himâyah, Mahnûd 'Alî. Ibn Hazm: Biografi, Karya dan Kajiannya tentang Agama-agama, terj. Halid Alkaf. Jakarta: Lentera Basritama 2001.

Hitti, Phillip K. The Arabs a Short History. London \& New York: Macmillan, t. th.

Ibn Hazm. al-Ushûl wa al-Furu'. Kairo: Dâr al-Nahdah al-'Ilmiyyah, 1978.

Ibn Hazm. al-Fishâl fî al-Milâl wa al-Ahwâ' wa an-Nihâl, jilid II. ttp: Dâr al-Fikr, 1317.

Ibn Hazm. al-Inkâm fì Ushûl al-A $\underline{\text { Hâm }}$, jilid II. Beirut: Dâr al-Kutûb al'Ilmiyyah, 1985.

Ibn Hazm. al-Muhallâ, jilid IX. Damaskus: Idârah at-Tibâ'ah, 1352 H.

Ibn ㅂazm. al-Nubzâh al-Kâfiyâh fi Ahkâm Ushûl al-Din. Beirut: Dâr alKutub al-'Ilmiyyah, 1975.

Kelib, Abdullah. Hukum Islam. Semarang: PT. Tugu Muda Indonesia, 1990.

Krippendroff, Klaus. Analisis Isi: Pengantar Teori dan Metodologi, terj. Farid Wajidi. Jakarta: Rajawali Pers, 1991.

Laylah, Abu. "An Introduction to the Life and Work of Ibn Hazm", The Islamic Quarterly, volume XXIX, no. 2 (1985).

Makkî, Al-Thahir. Dirâsat 'an Ibn Hazm. T.tp.: Maktabah Wabiyyah, $1397 \mathrm{H}$.

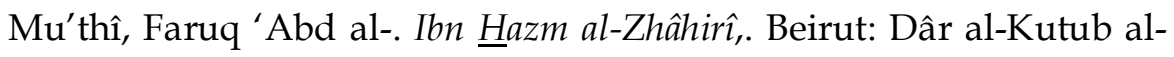
'Ilmiyyah, 1992.

Mughniyah, Muhammad Jawad. Fiqih Lima Madzhab, terj. Masykur A. B., Afif Muhammad, dan Idrus al-Kaf. Jakarta: PT. Lentera Basritama, 2000.

Mukhtar, Kamal. Ushul Figh. Jakarta: Jasa Usaha Mulia, 1995. 
Ramulyo, Mohd. Idris. Hukum Perkawinan Islam. Jakarta: Bumi Aksara, 1996.

Siregar, Amri. Ibn Hazm Metode Zhâhirî dalam Pembentukan Sumber Hukum Islam. Yogyakarta: Belukar, 2009.

Soekanto, Soerjono. Pengantar Penelitian Hukum. Jakarta: UI Press, 1986.

Soemiyati. Hukum Perkawinan Islam dan Undang-Undang Perkawinan, Edisi Pertama. Yogyakarta: Penerbit Liberty, 1982.

Syarqawi, Abd al-Rahmân al-. A'immah al-Fiqh al-Tis'âh, terj. al-Hamid Husayni. Bandung: Pustaka Hidayah, 2000.

Syawkâni, Al-. Irsyâd al-Fuhûl, juz III. Beirut: Dâr al-Fikr, 1992.

Watt, Montgomery. A History of Islamic Spain. Eidenbergh: The University Press, 1977.

Yatim, Badri. Sejarah Peradaban Islam, cet VII. Jakarta: Raja Grafindo Persada 1998.

Yuslem, Nawir. Ulumul Hadits. Jakarta: PT Mutiara Sumber Widya, 2001.

Zuhaylî, Wahbah al-. al-Figh al-Islâmi wa Adillatuhû, juz VII. Berut: Dâr al-Fikr, 1985. 